\title{
Yabancı dil öğretiminde ölçme değerlendirme unsuru olarak test sistemi ve test sisteminin Rusça öğretiminde kullanımı
}

Hüseyin PARLAK

\begin{abstract}
APA: Parlak, H. (2020). Yabancı dil öğretiminde ölçme değerlendirme unsuru olarak test sistemi ve test sisteminin Rusça öğretiminde kullanımı. RumeliDE Dil ve Edebiyat Araştırmaları Dergisi, (18), 520-538. DOI: 10.29000/rumelide.706299
\end{abstract}

\section{$\ddot{\mathbf{O} z}$}

Eğitim programının öngörülen standartlarını yerine getirirken öğretilen bilgilerin öğrenciler tarafından ne kadar anlaşıldığını görebilmek için ölçme ve değerlendirme yöntemini belirleyebilmek oldukça büyük bir önem arz etmektedir. Bu yüzden bahsetmiş olduğumuz bu değerlendirmenin doğru ve kesin yapılabilme konusu günümüzde güncelliğini korumaktadır. Ölçme ve değerlendirme yöntemini başarılı bir şekilde gerçekleştirebilmek ve bu konuya objektif yaklaşabilmek için öğrencilerin bilgi düzeylerinin kontrolünün de çeşitlilik içermesi önemlidir. Bilindiği üzere yüksek eğitim kurumlarındaki yabancı dil eğitimi veren fakültelerde öğrencilerin edindikleri yabancı dil seviyelerini ve bu dildeki bilgi ve becerilerini ölçmek üzere farklı ölçme değerlendirme kıstasları uygulanmaktadır. Bu kıstaslar klasik yazılılar, sınava yönelik araştırma ödevleri ve testlerdir. Bunların arasında testler hem öğretmene hem de öğrenciye kazandırdıkları bakımından çalışmamızda irdelenmiştir. Test sistemi sadece yabancı dil eğitiminde değil aynı zamanda hayatın birçok alanında sıklıkla kullanılan, hem testti yapan hem de teste tabi tutulan şahıslara birçok avantaj sağlayan bir ölçme değerlendirme unsurudur. Ölçme değerlendirme unsuru olarak test sistemi sonuçlara daha objektif yaklaşılmasını, zaman kaybının en aza indirgenmesini, eksikliklerin hızlı tespiti ve bu sayede de eğitim sürecine hızlı müdahaleyi mümkün kılar. Çalışmamızda test sisteminin tarihsel gelişiminin yanında genel olarak yabancı dil eğitimine kattıkları ve özellikle de Rus Dili ve Edebiyatı bölümlerinde test sisteminin kullanılması ile ilgili naçizane görüşlerimiz yer almaktadır.

Anahtar kelimeler: Test, yabancı dil, dil seviyesi, ölçme, değerlendirme.

\section{Test system as a means of assessment in Russian language teaching and usage of test system in teaching Russian}

\begin{abstract}
Abtract
It is of great importance being able to determine assessment and evaluation style to be able to detect how much the instructions have been understood by the students while fulfilling the foreseen standards of education program. Thus, the matter of fulfilling the aforementioned assessment accurately and in great certainty still keeps its up-to datedness. It is also important to vary the detection methods of knowledge level of the students to be able to actualize assessment and evaluation method successfully and approach this matter objectively. As known, various assessment and evaluation methods have been applied to assess the language the students acquire in faculties of higher education institutions. Those methods are exams, research projects and tests. Among those methods, tests have been closely examined in our study about what they let the tutors and students
\end{abstract}

1 Dr. Öğr. Üyesi, Erciyes Üniversitesi, Edebiyat Fakültesi, Rus Dili ve Edebiyatı Bölümü (Kayseri, Türkiye), huseyinprlk@mail.ru, hparlak@erciyes.edu.tr, ORCID ID: oooo-0002-8889-3901 [Makale kayıt tarihi: 15.10.2019-kabul tarihi: 20.03.2020; DOI: 10.29000/rumelide.706299] 


\begin{abstract}
acquire. Test system is an assessment and evaluation process which is not only used in language teaching but also used in various fields in life and it provides advantage to both the people taking the test and applying them. Test system as a means of assessment and evaluation system enables to approach the outcome more objectively, to minimize the waste of time, to detect the defects and intervene into the education environment rapidly. Apart from the test system's historical development and its contribution to language teaching, our humble ideas about its usage in Russian Language and Literature will be given in our study.
\end{abstract}

Keywords: Test, foreign language, language level, measuring, evaluation.

\title{
Giriş
}

Yabancı dil eğitiminde belirlenen hedeflere ulaşabilmek ve verilen bilgilerin öğrenciler tarafından anlaşılma seviyesini objektif olarak tespit edebilmek için ölçme ve değerlendirme yönteminin itina ile seçilmesi gerekmektedir. Değerlendirmenin en doğru ve en kesin şekilde yapılaması günümüzde de güncelliğini korumaktadır. Öğrencilerin bilgi düzeylerinin kontrolünde kullanılan ölçme ve değerlendirme yönteminin çeşitlilik içermesi de önem arz eden konulardan bir tanesidir. Bu çeşitlilik bir taraftan öğrencilerin öğrendikleri dildeki beceri ve bilgilerini kontrol etmeye diğer taraftan ise öğrendikleri dilde kendilerini edebi, ilmi ve gündelik alanda ifade edebilmelerine yönelik olmalıdır.

Dil öğretiminde ölçme, öğrencinin dil kapsamındaki ayırıcı niteliklerini belirleme sürecidir; test de bu amaçla düzenlenen ölçme aracıdır. Değerlendirme ise, test sonuçlarına ve belirli ölçütlere göre kararlara ulaşma sürecidir. Yabancı dil öğretiminde ölçme ve değerlendirme yapılırken, okuma, yazma, dinleme ve konuşma becerilerinin tümünün esas alınması gerekmektedir. Bu durumda, her bir beceri için farklı testler veya ölçme araçları kullanılır. Öğretmenler, geniş boyutlu dil ölçme amaçları için farklı testler ve sınama biçimleri (yeterlilik, başarı, bulgulayıcı ve/veya yerleştirme amaçlı sınama, doğrudan ve dolaylı sınama, ayrık nitelikli ve bütüncül sınama, ölçüm ve ölçüt temelli sınama, öznel ve nesnel sinama, iletişimsel sınama, vb. gibi) kullanabilir; fakat bunları seçerken öğrencilerin öğrenim gördükleri farklı bölümleri, dil düzeylerini ve öğrenme biçimlerini göz önünde bulundurmaları gerekir (Dönder ve diğerleri, 2012, akt. Karakuş, 2013, s. 17). İşte bu yüzdendir ki Rus Dili ve Edebiyatı alanında eğitim veren bölümlerin araştırmacıları, öğretim elemanları ölçme değerlendirme unsuru olarak test sistemini kullanırken Rusçayı diğer dillerden ayıran özellikleri göz önünde bulundurmalıdırlar.

Ölçme uygulamalarında ilk adım amaç ve kapsamın belirlenmesidir. İkinci aşama ise ölçülecek davranışın seçilmesidir. Öğrenci açısından bakıldığında öğrencilerin istenilen niteliklere sahip duruma gelip gelmediklerinin, bir başka deyişle istendik davranışların öğrenciler tarafından kazanılıp kazanılmadığının sürekli olarak test edilmesi, varsa eksikliklerinin belirlenerek bunların giderilmesine yönelik çalışmaların gerçekleştirilmesi gereği vardır (Karslı, 2003, akt. Altmışdört, 2010, s. 175).

Öğrencilerin bilgi düzeylerini ve sınavlarda kendilerine verilen soruların zorluk derecelerini ölçme esnasında kullanılan test sistemi modern dil eğitimi için önemli bir unsurdur. Her ne kadar öğrencileri ezber yapmaya ittiği görüşü olsa da günümüzde modern dil eğitiminin önemli bir parçası olan test sistemi olmadan dil eğitim sürecini yönetmek bir bakıma zor olacaktır. Ders, sunum, dil laboratuvarı çalışmaları gibi daha geleneksel olan dil öğretim yöntemleri ile sözlü ve yazılı sınavlar yabancı dil öğretiminde elbette ki önemlerini korumaktadırlar. Modern dil öğretimi ile birlikte gelişen test sistemi geleneksel yöntemlerin kullanılmasını da teşvik etmektedir. 
Test system as a means of assessment in Russian language teaching and usage of test system in teaching Russian / H. Parlak (pp. 520-538)

Yabancı dil öğretiminde kullanılan test sistemi kendi içerisinde bazı yetersizliklere sahip olsa da öğrencilerin bilgi düzeylerinin ölçülmesi ve değerlendirilmesinde kullanılan teknolojik unsurlardan birisidir. Bilindiği gibi öğrencinin dile hâkim olma seviyelerini ölçme esnasında önemli bir yeri olan test uygulamasından sonra elde edilen sonuçlara göre öğrencilerin bilgi düzeyi sayısal değerler olarak öğrencilere iletilebilmektedir. Yapılan bu sayısal değerlendirme bizlere eğitimin, üretimin ve bilimin, yani hangi alan olur ise olsun hiçbir kavramın sayısal değerler olmadan hayatta kalamayacağını da göstermektedir. Değerlendirme, öğrenci ve öğretmenin edimini ölçmek, ileriye yönelik eğitim gereksinimlerini belirlemek ve programın varsa eksik yönlerini ortaya çıkarmak amacıyla yapılır. Değerlendirmede, testlerin doğrudan konuyla etkili olup olmadığı, amaca ulaşıp ulaşmadığı, zamanlamanın iyi olup olmadığı, öğrencilerin ilerleme sağlayıp sağlamadığı, öğrencilerin kendilerini değerlendirip değerlendirmediğine yönelik veriler elde edilir. (Hedge, 200o, akt. Altmışdört, 2010, s. 176) Bilgilerin öğretimi ve kontrolü esnasında kullanılan test sistemi sayesinde yabancı dil eğitimindeki zaman kaybı en aza indirgemektedir. Bu yüzdendir ki test sistemi yabancı dil eğitiminin ayrılmaz bir parçasıdır. Yabancı dil eğitiminin çağdaş yöntemleri eğitimden beklenen üst seviyelere ulaşabilmek için modern teknolojinin kendisine sunmuş olduğu en son imkânlardan faydalanmalıdır.

Dil eğitiminde kullanılan pedagojik testlerin kısaca tanımını yapacak olur isek: "kolaydan zora doğru ilerleyen, öğrencilerin dildeki bilgi ve beceri seviyelerini ölçmeye yönelik kullanılan özel alıştırma sistemine pedagojik test denir" diyebiliriz. Öğrencilerin kavramış olduğu bir konunun seviyesini ölçebilme amacı ile kullanılacak olan testler, ölçme ve değerlendirme işlevini tam olarak yerine getirebilmek için bahsi geçen konuyu tamamı ile kapsayacak nitelikte olmalıdır. Ölçülmesi gereken dil seviyesine göre testler 10-20 sorudan oluşan kısa, 500'e kadar ve daha fazla sorudan oluşan orta ve uzun testler olarak karşımıza çıkabilmektedir. (Олейник, 1991, стр. 7)

\section{Yabancı dil öğretiminde de kullanılan test sisteminin gelişimi}

Test nedir, geleneksel ölçme ve değerlendirme yöntemlerinden farkı nedir ve yabancı dil öğretiminde testlerden ne zaman faydalanmak gerekmektedir?

Test sistemini geleneksel yöntemlerden ayrılan en önemli özellik test sonuçlarının diğer sinav sonuçlarına göre her zaman daha net sayısal değerler vermesidir. Bu yüzden test sonuçlarına göre yapılacak olan değerlendirme esnasında geleneksel yöntemler sonrası yapılan değerlendirmeden farklı olarak öğretmen daha nesnel davranır. Test sonuçları öğretmenin herhangi bir öğrenciye karşı beslediği sempati veya antipatisinin önüne geçerek onu öznellikten uzaklaştırıp daha nesnel değerlendirme yapmasını sağlar. Testler, öğretimi sınırlamamalı, tarafsız olmalı, zorluk derecesi ayarlanmalıdır. (Lee, 2000, akt. Altmışdört, 2010, s. 176)

Tanı koyma yöntemi olarak test sisteminin ortaya çıkması ve kullanılmaya başlanması oldukça eskiye dayanmaktadır. Milattan önceki eski doğu ülkelerinde devlet kadrolarında görev yapacak şahıslar seçilirken test sisteminin kullanıldığına dair bulgulara rastlanmıştır. Yalnız elde edilen bulguların hepsi modern zamanda kullanılan test sistemi ile kıyaslanamaz. (Кадневский , 2004, стр. 35)

Test sisteminin eğitim alanında yoğun olarak kullanımı batı ülkelerinde başlamıştır. Test sistemi ilkokullarda 1892 yılından itibaren Francis Galton tarafından kullanılmaya başlanmıştır. 1894 yllında okullarda ilk defa başarı ölçme testleri kullanılmaya başlanmıştır, öğrencilerin farklı derslerdeki başarılanı ölçmeye yönelik olan bu testlerden ilki ise öğrencilerin imla kuralı bilgilerini ölçmeye yönelik olanlardır. Amerikalı eğitimci W.A.MacCall testleri pedagojik ve psikolojik olarak ikiye ayırmıştır. 
W.A.MacCall pedagojik testlerin kullanım amaçlarını belirlemiştir. Yalnız pedagojik test ölçümlerinin kurucusu Amerikalı psikolog Edward Lee Thorndike'tır. İlk pedagojik testleri kendisinin oluşturduğu bilinmektedir. Pedagojik test sisteminin kurucusu olan Edward Lee Thorndike okullarda test sisteminin uygulanmasını üç etapta toplamıştır:

1. Araştırma dönemi(1900-1915). Adı geçen bu dönemde Fransız psikolog Alfred Binet tarafından test sisteminin anlaşılması ve testlerin öğrenci hafızasına, dikkatine ve diğer zihinsel aktivitelerine olan etkileri üzerine çalışmalar yapılmıştır. Bu çalışmalar esnasında test sisteminin geliştirilmesi ve gelişen testlerin zihinsel faaliyetler üzerindeki etkileri incelenmiştir.

2. Bunu takip eden sonraki 15 yll ise eğitimsel test sisteminin tam olarak anlaşılıp eğitimdeki yeri ve rolünün konuşulduğu, tartışma ve yorumunun yapıldığı yıllar olmuştur. Bu yıllarda Edward Lee Thorndike'ın okullarda verilen birçok derse yönelik test çalışmalarının yanı sıra, kendisi gibi eğitimci ve psikolog olan bilim adamlarının test sitemi üzerine yapmış olduğu çalışmalar da görülür. Örneğin psikolog Charles Spearman test sisteminin standartlaştırılması için korelasyon analiz yönteminin kullanılmasını önermiştir.

3. 1931 yılı itibarı ile eğitimsel test siteminin gelişim etabı başlamıştır. Araştırmacıların çalışmaları testlerin nesnelliğini arttırmaya, test sonuçlarındaki değerlendirmelerin tarafsız olmasına, tek amaca yönelik daha gelişmiş testlerin hazırlanmasına ve uygulanan testler sonucu elde edilen verilerin belirli bir sisteme bağlı olarak depolanabilmesine yoğunlaşmıştır.

Günümüzde ise modern test sistemi bilgisayar teknolojileri sayesinde oldukça kullanışlı bir konum elde etmiştir.

\section{Test sisteminin işlevleri ve sınıflandırılması}

Yüksek Öğretim Kurumlarında kullanılan yenilikçi test sistemleri birbirine bağımlı olan teşhis, eğitim ve öğretim diye ayırabileceğimiz üç işlevi yerine getirmektedir.

Test sisteminin teşhis işlevi: Teste tabi tutulan öğrencilerin bilgi seviye ve kalitelerinin ölçülmesidir, teşhis edilmesidir. Yabancı dil öğretiminde uygulanan testler sayesinde öğrencilerin bilgi seviye ve kalitesinin hızlı ve kapsamlı olarak nesnel bir şekilde ölçülebilmesi test sistemini diğer yöntemlerden ayırmaktadır.

Test sisteminin öğretim işlevi: Teste tabi tutulacak olan öğrenciler hazırlanmaları gereken test sınavları sayesinde kendilerine verilen bilgileri öğrenmeye motive olurlar. Öğretim işlevinin arttırılabilmesi için testlerin daha önce hazırlanmış benzer örnekleri öğrencilere evde çalışmaları için dağıtılabilir ve bu örnek testlere sonuca götürücü ipuçları yerleştirilebilir.

Test sisteminin eğitim işlevi: Testlere tabi tutulacak öğrenciler testlerin belirli aralar ile yapılmasından dolayı gözle görülür bir disiplin içerisine girerler ve bu sayede kendilerine verilen bilgileri sürekli tekrar ederek kendilerini geliştirirler. Öğrencilerin bilgi düzeylerini belirleme de öğretmenin önemli yardımcılarından bir tanesi olan test sistemi birbirlerini konulara göre takip eden testlerden oluştuğu için sürekli test olan öğrencilerin dillerinde gözle görülür değişimler olur.

Öğrencilerin bilgi seviyelerinin kontrolü için iki yöntem bulunmaktadır: Nesnel Yöntem ve Öznel Yöntem. (Помякшева, 2009, стр. 57) 
Test system as a means of assessment in Russian language teaching and usage of test system in teaching Russian / H. Parlak (pp. 520-538)

Sınav sonuçlarının öznel kontrol yöntemi ile incelenmesi demek öğrencinin edindiği bilgi ve becerileri değerlendirirken öğretmenin öğrenci hakkındaki şahsi bakış açısından da değerlendirmesi anlamına gelmektedir ve bu değerlendirmede öğretmenin kanaat kullanması oldukça doğaldır. Öznel kontrol yöntemi daha çok yazılı ve sözlü sınavlarda kullanım için uygundur.

Sınav sonuçlarının nesnel kontrol yöntemi ile incelenmesi demek ise öğrencinin edindiği bilgi ve becerileri değerlendirirken öğretmenin öğrenci hakkındaki şahsi bakış açısını kullanmadan değerlendirmesi anlamına gelmektedir. Nesnel kontrol yöntemi ise test sistemi ile yapılan sınavlar için uygundur.

Yabancı dil öğretiminde kullanılan testlerin niteliklerine göre aşağıdaki gibi sınıflandırılması mümkündür:

- Amaçlarına göre testler: bilgilendirici, tanımlayıcı, öğretici, motive edici ve onaylayıcı testler.

- Hazırlanış amaçlarına göre testler: ölçünlü, ölçünsüz testler.

- Soruların hazırlanma yöntemine göre testler: belirleyici, değişken ve dinamik testler.

- Uygulanış teknolojisine göre testler: kâğıt kullanımlı, kâğıt artı optik okuyucu kullanımlı, özel cihazların kullanıldığı tam ölçekli ve bilgisayar testleri.

- Verilen soru tipine göre testler: kapalı tip, açık tip, eşdeğerlilik belirleyen, sıralamayı sağlayan testler.

- Geri dönüşüm sağlayan testler: geleneksel ve uyarlamalı testler.

Yukarıda adı geçen tüm test türleri hazırlanırken en çok dikkat edilmesi gereken nokta ise öğrencilerin soruları tahmini olarak değil de bilerek yapmalarına yönelik olmalarıdır. (Аванесов, 2002, стр. 68)

Birçok araştırmacının fikrine göre testler tahmine dayalı değil de çözüm ilkesine yakın bir anlayış ile hazırlanır ise öğrencilerin cevap verirken izledikleri yol, yaptıkları hatalar ve bu hataları en aza indirgeme yöntemi şu şekilde olmalıdır:

- Öğrenciler cevap şıları arasından daha kapsamlı ve daha genel olan şıkkı seçmektedirler. Bu yüzden soruların cevapları hazırlanırken daha kısa ve net bilgilerden faydalanılmalıdır.

- Eğer cevap şıkları birbirlerini takip eden bağlantılı bir yapıya sahip olur ise öğrencilerin genelde ortadaki şıkları seçtiği gözlemlenmiştir, bu düşünce yapısı da öğrencileri yanlışa sürüklemektedir. Bu yüzden bu tip bir uygulamadan kaçınılmalıdır.

- Anlaşılmayan zor sorularda öğrencilerin cevap olarak daha bilimsel ama yanlış olan yeni kelimeleri seçtikleri gözlemlenmiştir. Bu yüzden soruların anlaşılır olmasına dikkat edilmelidir.

- Öğrenciler cevaplama aşamasında şıklarda öğrendikleri konuyu çağrıştıran kelimeler var ise bu kelimeler doğru olmadığı halde seçimlerini yapmaktadırlar. Öğrencileri zor durumda bırakmamak için daha net kelimeler kullanılmalıdır.

Şıklı cevaplarda şık sayısının en az beş olması ise öğrencilerin tahmin ile değil de düşünerek ve bilerek cevap vermelerini sağlayacaktır. 
Bu durumdan dolayı kendi bilgisine değil de içgüdüsüne güvenen öğrencileri aşağıda belirtildiği şekilde tanımlamamız mümkündür:

- Şanslı öğrenciler; 25 sorudan 8 veya daha fazla soruya doğru cevap verebilen öğrencilerdir ve bu grup genelin \%7'sini oluşturmaktadır.

- Orta derece şanslı olan öğrenciler; 25 sorudan 5 veya 7’sine cevap verebilen öğrencilerdir ve bu grup genelin \%67'sini oluşturmaktadır.

- Şanssız öğrenciler; 25 sorudan 5’ine cevap verebilen öğrencilerdir ve bu grup genelin \%26’sını oluşturmaktadır.

\section{Yabancı dil eğitiminde kullanılan testlerin öğretmen ve öğrenciye katkıları}

Bilgisayar teknolojileri sayesinde gerçekleştirilen testler günümüzde uygulanan test sistemlerinin en önemlilerinden birisidir. Yabancı dil eğitimi alanında kullanılan test sisteminde bilgisayar teknolojilerinin kullanımı klasik test sistemlerine göre hem zaman hem de kâğıt israfından tasarruf edilmesini sağlamaktadır. Bilgisayar teknolojilerinin yabancı dil eğitiminde ve test sisteminde kullanılması ise üniversitelerdeki yabancı dil eğitim seviyesini daha modern kılarak bir üst seviyeye taşımaktadır. Gerek bu teknolojiyi kullanarak gerekse kâğıt üzerinde uygulanan test sistemlerinin genel amacı başta da belirttiğimiz gibi öğrencilerin edindiği bilgileri daha net bir şekilde ölçmektir. Yabancı dil eğitiminde kullanılan testleri hazırlarken üniversitelerde yabancı dil eğitimi veren biz öğretmenlerin görevi ise hazırladığımız testlerin sadece öğrencilerin yapmış oldukları hataları ortaya çıkaran ve bu hatalara göre not vermemizi sağlayan bir test sistemi yerine hataların yapılma sebeplerini ortaya çıkarıp bu hataları düzeltmeye yönelik testler hazırlamak olmalıdır. Bu sayede öğrenciler eğitim sürecine aktif bir şekilde katılıp kısmen de olsa eğitim sürecini kendi kontrolleri altına alabilirler.

Öğretmen yapmış olduğu test sonuçlarına göre öğretim sürecini kontrol altında tutup, gerektiği gibi yönlendirebilir. Bunun yanında test sonuçlarına göre öğretmen hangi konuda öğrencilerin zorlandığını görerek derslerde anlaşılmayan konuya daha fazla ağırlık verip, mümkün olan en iyi sonuca ulaşabilir. Test sonuçlarını değerlendirirken öğretmen her öğrencinin eksik olduğu konuyu görebildiği için öğrenci hatalarının giderilmesinde ne yapılması gerektiğine daha kolay karar verip, bu eksiklikleri giderebilir. Bu sayede öğretmen öğrencilerin başarı ivmelerini kolaylıkla kontrol edebilir. Başarı ivmeleri kontrol altında olan öğrencilerin başarı yüzdesine göre öğretmen öğrencilere farklı ödevler verebilir. Ĕ̆itimde bu tür bir yaklaşım öğretmene dersleri daha esnek kılma ve öğrencilerin problemleri ile birebir ilgilenme imkânı vermektedir. (Помякшева, 2009, стр. 59)

Öğrencinin öğrendiği yabancı dildeki bilgi ve beceri düzeyini belirleme için kullanılan test sisteminin diğer klasik sınav sistemlerine göre birçok artısı bulunmaktadır. Test sistemi sayesinde eksikliklerini gideren öğrenci bir üst etaba hızlıca geçebilir. Test sistemi hem öğrenciye hem de öğretmene bir konunun hangi seviyede öğrenildiğinin hızlıca anlaşılma imkânını sağlamaktadır. Sınavlarda uygulanan testler özellikle de yabancı dil eğitiminde, öğrencilerin işlenen yeni konudaki hem gramer hem de kelime bilgisinin hangi seviyede öğrenildiğinin belirlemesinde öğretmene yardımcı olur. Bu sayede de öğretmen eksik kalan ve anlaşılmayan konulara müdahale etmede zamandan tasarruf eder. Erken teşhis edilen yanlışlar ve anlaşılmayan konuların düzeltilmesi ve doğru öğrenilmesi sayesinde ise daha doğru bir dil eğitimi verilmiş olur. Klasik yazılıların kontrolünde karşılaşılan zaman kaybı test siteminde olmadığı için testler hem öğretmen üzerindeki zaman kaybı baskısını hem de öğrenci üzerindeki bekleme 
Test system as a means of assessment in Russian language teaching and usage of test system in teaching Russian / H. Parlak (pp. 520-538)

baskısını azalmaktadır, diğer yandan ise daha önce de belirttiğimiz gibi öğretmeni öznellik probleminden kurtarmaktadır. (Фоменко, 2008, стр. 70)

Yabancı dil bilgi ve becerisini ölçmede kullanılan test sistemi diğer klasik sistemlere göre öğrencilerin derse karşı olan motivasyonunu da arttırmaktadır. Yabancı dil eğitiminde uygulana test sisteminin diğer bir faydalı yanı ise eğitim sürecini hem öğrenci hem de öğretmen için kolaylaştırıyor olmasıdır. Test sisteminin eğitimde sağlamış olduğu kolaylık daha çok yüksek eğitim kurumlarında gözlemlenmektedir. Yapılan gözlemler sonucunda test siteminin öğrencilerin derslerdeki aktifliğini arttırdığı, öğretmen ve öğrenci arasındaki psikolojik havayı yumuşattığı ve oluşan bu ortam sayesinde ise verilen eğitimden daha fazla fayda sağlandığı gözlemlenmiştir.

Bilkent Üniversitesi Yabancı Diller Bölümü’nde “Testlerin Sıklı̆̆ının Etkisi Üzerine Deneysel Bir Çalışma" (1992) adlı yapılan tezde ise testlerin sıklık derecesine göre başarı durumuna etkisi incelenmiştir. Ön-test ve son-testlerin öğrencilere sıklıkla verilmesinin başarı üzerinde belirgin bir değişikliğe neden olmadığını göstermiştir. Ancak, belirli aralıklarla yapılan testlerde öğrencilerin başarısının daha arttı̆̆ı ortaya çıkmıştır. (Altmışdört, 2010, s. 177)

Test sisteminin yabancı dil eğitimi veren öğretmenler tarafından yoğun olarak kullanılmasının sebeplerinden birisi ise verilen bilgilerin ne sevide anlaşıldığının kontrolünün yapılmasının yanında dil eğitiminde eksik kalmış konuların hızlıca belirlenip bu eksik kalan konuların tekrar işlenmesini hızlandırmaktadır.

\section{Test sisteminin Rusça öğretiminde kullanımı}

Tüm bu olumlu yönlerine rağmen Rusçanın yabancı dil olarak öğretildiği yükseköğretim kurumlarımızda öğrencilerin dersten geçmelerini sağlayacak sınavlar esnasında test sisteminin genelde teorik bilgilerin verildiği derslerde kullanılmasının daha uygun olacağı görüşünü savunmaktayız. Rusça yapısı bakımından el yazısının önemli olduğu bir dil olmasından dolayı özelliklede dil sınavlarında öğrencileri yazıya ve kendi başlarına cümle kurmaya yönlendiren sınavların yapılmasının faydalı olacağını düşünmekteyiz. Dil ağırlıklı derslerde kullanılacak olan testler daha çok anlaşılmayan konuların tespitine yönelik, quiz tarzı, not verilen ve ana sınava ek katkı sağlayan sınavlar niteliğinde olmalıdır.

Çalışmamız dâhilinde Rusça öğretimindeki dil, edebiyat ve genel kültür derslerinin test sistemine göre hazırlanan sınav soruları incelenip analizleri yapılmıştır.

Uygulamalı Metin Analizi, Çağdaş Rus Dili, Pratik Rusça, Morfoloji, Rus Kelime Bilgisi, Sentaks, Üslup Bilimi, Metin İncelemesi gibi dil derslerinin sınavlarında test tipi sorular ile birlikte öğrencilerin dil pratiğini geliştirecek ve kendilerini Rusça ifade etmeye yönlendirecek soru tiplerinin de kullanılması faydalı olacaktır.

Tablo 1:

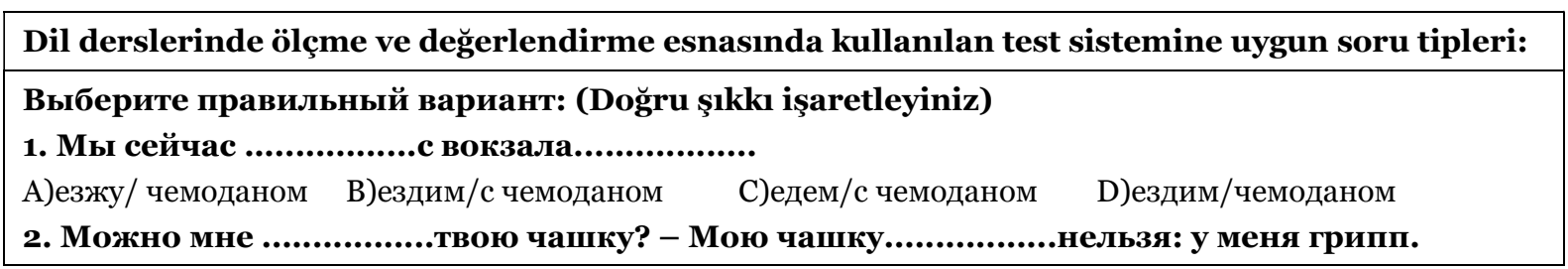




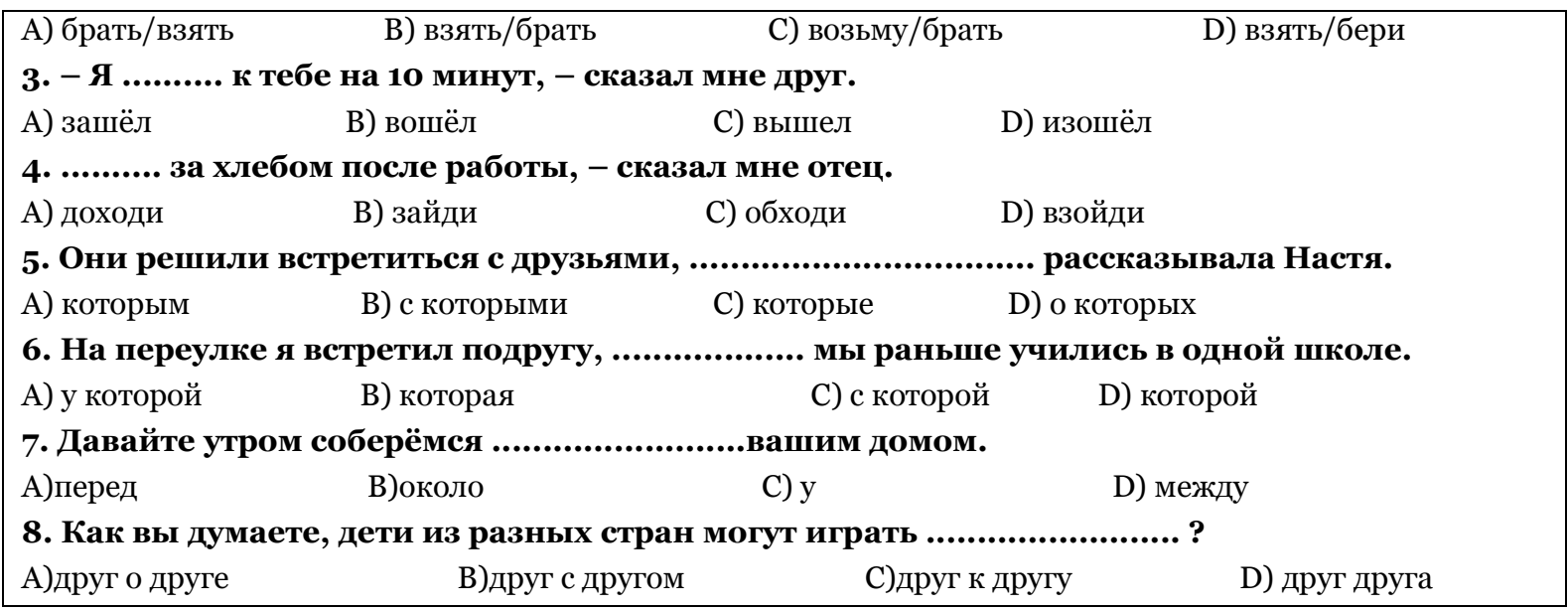

Tablo 1'de verdiğimiz Rusça dil eğitiminde kullanılan ve test prensiplerine göre hazırlanan soru tipleri öğretmene bir konunun anlaşılma seviyesinin hızlı tespiti esnasında oldukça yardımcı olacak ve zaman kazandıracak soru tipleridir. Ancak, yapmış olduğumuz gözlemler bu soru tiplerinin öğrenciyi kendini ifadeye yönlendirmediğini göstermiştir. Öğrenciler bu tip soruları çözerken ezberledikleri dilbilgisi kuralları dâhilinde cevabı bulmaya çalışmaktadır. Öğrencilerin Rusça cümle yapısını kullanarak kendilerini ifade edebilmeleri, gramer kurallarına uygun cümleler kurabilmeleri ve aynı zamanda yazım yeteneklerini de geliştirebilmeleri için yukarıda verdiğimiz soru tiplerinin Tablo 2'de vereceğimiz klasik sınav sistemine uygun olacak şekilde kullanılması da faydalı olacaktır.

Tablo 2:

Dil derslerinde ölçme ve değerlendirme esnasında kullanılan klasik sisteme uygun soru tipleri:

1. Составьте предложния с глаголами, в настоящем времени: (Aşağıda verilen fiiller ile şimdiki zamanda cümle kurunuz.)

Идти

Ехать

2. Составьте предложения с данными приставочными глаголами: (Aşağıda verilen ön ekli fiiller ile cümle kurunuz.)

Доходить

Отходить

Переходить

Заходить

3. Составьте четыре сложноподченённых предложения с данными союзами: (Aşайıda verilen bağlaçları kullanarak dört tane karmaşık cümle kurunuz.)

Который

Чтобы

Для того чтобы

Как только

4. Составьте четыре сложноподченённых предложения с данными предлогами: (Aşаğıda verilen edatları kullanarak dört tane karmaşık cümle kurunuz.)

Перед

Около

$\mathrm{y}$

Между

5. Ответьте на вопросы по тексту. (Metnin sorularını yanıtlayınız.) 
Test system as a means of assessment in Russian language teaching and usage of test system in teaching Russian / H. Parlak (pp. 520-538)

Çalışmamız dâhilinde farklı sınıflardan 100 öğrenci ile yaptığımız örnek sınav sonuçları, dil derslerinde uygulanan test sisteminin klasik sistem sorularına göre daha kolay çözümlendiğini ve öğrencilerin daha yüksek notlar alabildiklerini bizlere göstermiştir. Öğrencilerin almış oldukları notlar bulundukları sınıflara göre de farklılık göstermiştir. Dil ve gramer sınavlarında üst sınıflardaki öğrenciler doğal olarak her iki sınav türünde de bir alt sınıftaki arkadaşlarına oranla daha yüksek not almıştır. Alınan sonuçları grafikler halinde aşağıda vermiş bulunmaktayız.

Test sistemine uygun sorular ile yapılan örnek sınav değerlendirme grafiği:

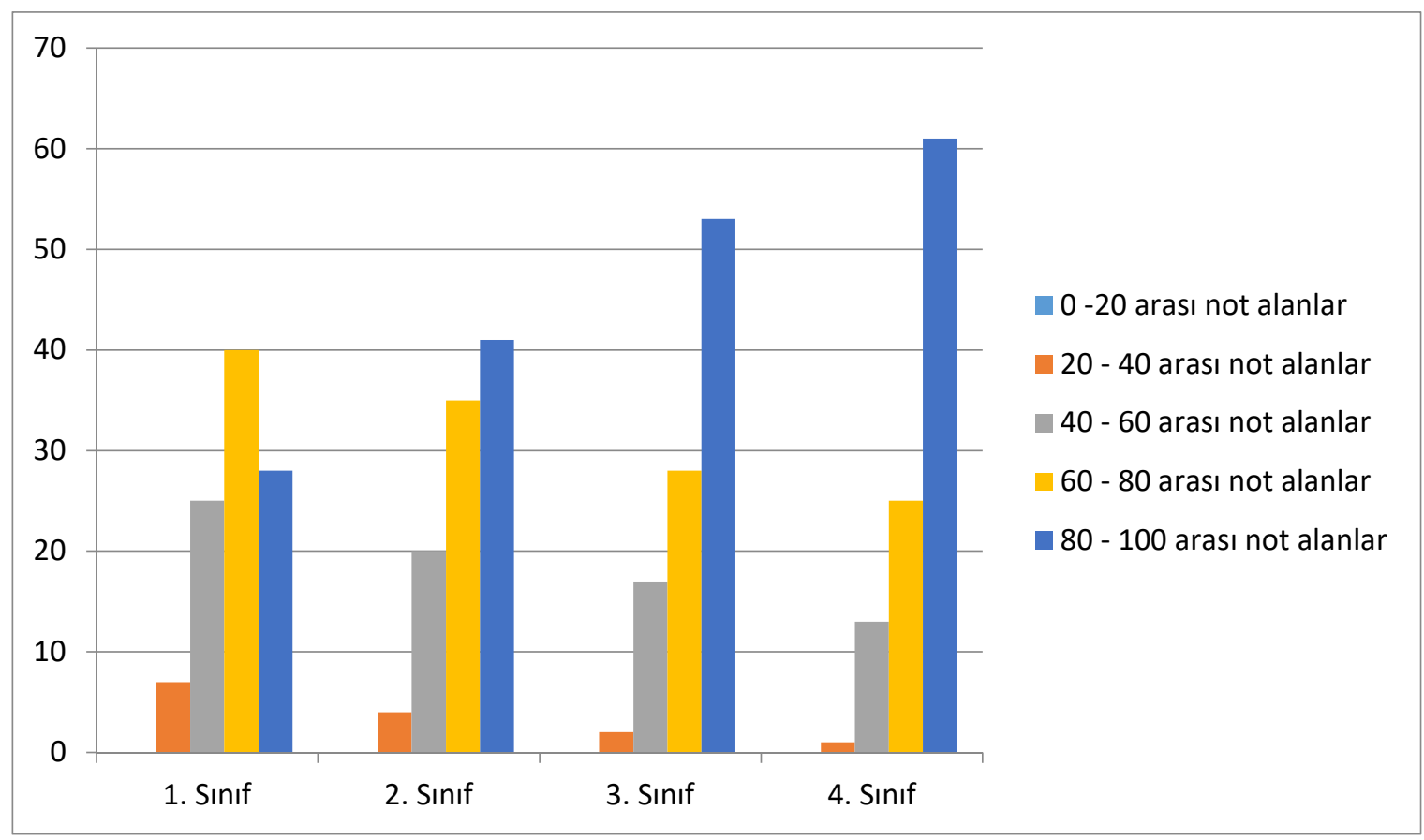

Grafikten de görüldüğü üzere pratik dersler olarak adlandırabileceğimiz dil ve gramer derslerine uygun olarak hazırlanan test sınavında öğrenciler kendilerine tanıdık gelen şıklar arasında seçim yaptıkları için başarı oranları daha yüksektir. Tüm sınıflarda o - 20 arası not alan yokken aynı zamanda da bulundukları sınıflara göre başarı oranları da artmaktadır. 80 - 100 arası not alan öğrenci sayılarının 2., 3. ve 4. sinıflarda arttığı gözlemlenmiştir. 
Klasik siteme uygun sorular ile yapılan deneme sınavının değerlendirme grafiği:

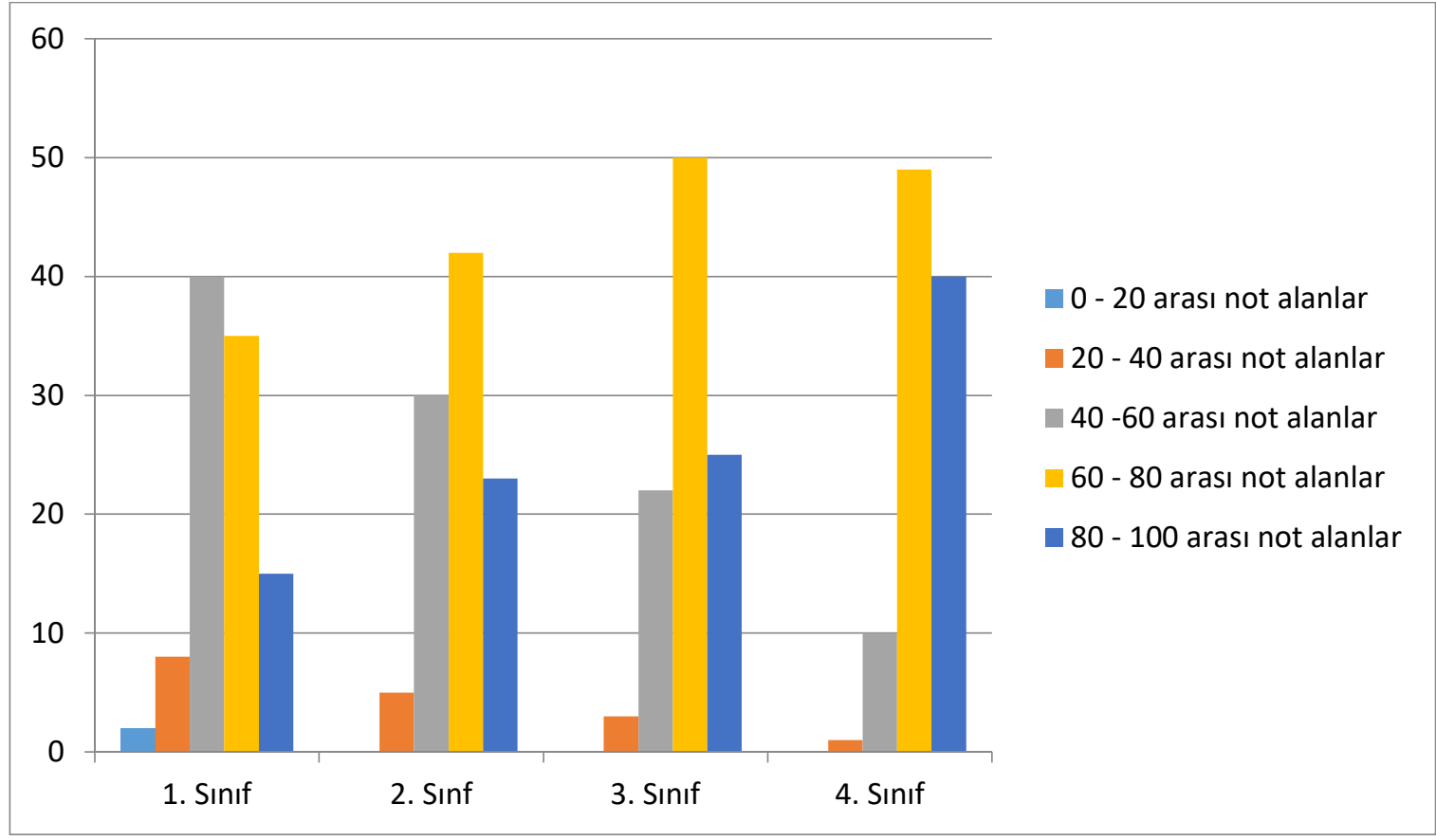

Klasik soru sistemi ile yapılan deneme sınavının sonuçları bize başarı oranının daha düşük olduğunu göstermektedir. Öğrenciler klasik soruları cevaplarken cümlenin tamamını kendileri kurmaları gerektiğinden dolayı zorlanmakta ve kurdukları cümleler düzgün cümle yapısına uygun olandan uzak kalabilmektedir. Bu sınav sonucunda hem o - 20 arası not alan öğrenci bulunmakta hem de 80 - 100 arası not alan öğrencilerin sayısında azalma görülmektedir.

Klasik Metinler, Rus Kültürü, 18.yy Rus Edebiyatı, 19.yy Rus Edebiyatı, Rus Sinema Tarihi, Rus Sinemasında 20.yy gibi edebiyat ve kültür derslerinin sınavlarında kullanılan test soruları öğrencilerin bu konulardaki bilgilerini hızlı bir şekilde ölçme ve nesnel değerlendirmenin en ideal yoludur. Bu tür derslerin sınavlarında asıl amaç öğrencilerin kendilerini Rusça ifade etmeleri değildir. Bu sınavların amacı öğrencilerin verilen konulara ne denli hâkim olduklarını ölçmek ve bu ölçümlere göre değerlendirmeyi kanaat değerlendirmesine gerek kalmadan yapabilmektir. Bu yüzden bu tip derslerin sınavlarında test sisteminin uygulanması oldukça doğaldır. Edebiyat ve kültür derslerinde uygulana ve test sistemine göre hazırlanmış soru örnekleri Tablo 3 'te verilmiştir. 
Test system as a means of assessment in Russian language teaching and usage of test system in teaching Russian / H. Parlak (pp. 520-538)

Tablo 3:

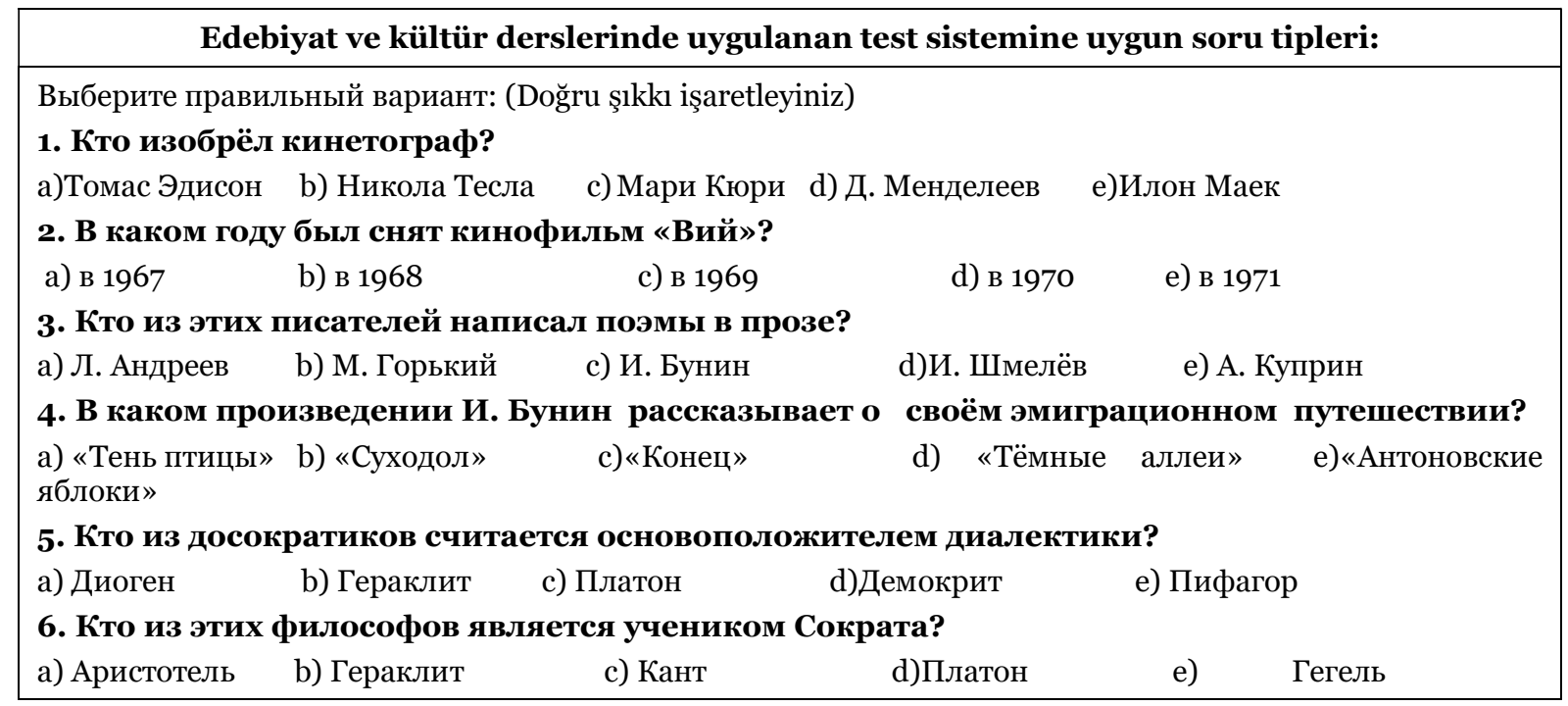

\section{Yabancı dil eğitiminde özelliklede Rus dili eğitiminde kullanılan test türleri}

Yabancı dil eğitiminde özelliklede Rus Dili eğitiminde kullanılan farklı test türleri bulunmaktadır. Bunları kısaca şu şekilde sıralayabiliriz:

Fonetik testleri:

Fonetik testleri üç büyük bölümden oluşur, işlevsel bölüm, araçsal bölüm, düzenleyici bölüm. Bu bölümlerden en büyüğünü işlevsel bölüm oluşturur. İşlevsel bölüm sorular karşısında soruya cevap veren öğrencinin tepkisinden yola çıkarak öğrenciyi teşvik etmeye yönelik olarak hazırlanan test çalışmalarını içerir. Bu çalışmalar (Ses benzerliği olan kelimeleri dinleyiniz veya kelimeleri okuyunuz) şeklinde hazırlanan sözlü veya yazılı testlerden oluşurlar. Verilen bu çalışmalarda öğrenci tepkisinin sözlü veya yazılı olması beklenir; örneğin (Okuduğunuz kelimelerin veya diyalogun ses kaydını yapınız, dinlediğiniz kelime grupları içerisindeki eş sesli kelimeleri yazınız veya eş sesli kelimeleri verilen tabloda işaretleyiniz) vb. Eğer verilen testlerde çoktan seçmeli bir durum söz konusu ise seçilecek şıklar arasında doğru ve yanlış şıklar ile beraber şaşırtıcı şıklarında olması öğrencilerin dikkatlerini daha da yoğunlaştırmak açısından önemlidir. Şaşırtıcı şıklar ne kadar çok olur ise öğrencinin dikkati aynı oranda yoğunlaşır ve aynı zamanda doğru şıkkı tahmini olarak bulma şansı daha da azalır.

Araçsal bölümde bulunması gereken öğeler:

- Testin hedef ve görevlerinin belirlendiği ve öğretmen kullanımı için hazırlanan bir kılavuz;

- Test yapan ve teste tabi tutulan yani öğrenci ve öğretmen için test ile yapılacak olan çalışmayı anlatan genel içerikli açıklama bölümü;

- Testte verilen soruların nasıl çözülmesi gerektiğini anlatan ve öğrenciye yardımcı olacak olan açıklama bölümü. 
Düzenleyici bölümde bulunması gereken öğeler:

- Test yapılan öğrencilerin, verilen sorulara uygun olarak cevabını işaretleyebileceği bireysel çalışma tablosu (optik kâğıt);

- Öğrencinin sözlü cevaplarını kayıt altına almaya yardımcı olacak cevap tablosu;

- Test kontrol süresini minimuma indirgemek için öğretmene yardımcı olacak olan cevap anahtarı veya tablosu;

Testlerin açlklama bölümünde test süresi, teste başlamadan önce yapılması gereken ön hazırlıklar ve test esnasında uyulması gereken kurallar mutlaka belirtilmelidir.

Fonetik dersi ile alakalı test seçimi ve hazırlanması esnasında öğretmenlerin öğretilen dilin özelliklerine dikkat etmeleri gerekmektedir. Rus dilinin yabancı dil olarak öğretilmesi için kullanılan fonetik testler aşağıda sıralanan materyalleri içermelidir:

- Farklı duyumlar için kullanılan tek ve ardışık sesleri;

- Farklı aksan örneklerini;

- Farklı telaffuz tiplerini;

Test materyalleri aynı zamanda kontrol edilmesi gereken konular ile bağlantılı olmalıdır.

Öğretilen fonetik konularının anlaşılmasına yönelik testlerin içeriğinde olması gereken çalışmaları şu şekilde sıralayabiliriz:

- Seslerin işaretler ile yorumlanması (yani + ve - işaretleri kullanılarak öğrencilerin sorun yaşadıkları seslerin belirlenebilmesi);

-Başlangıç etaplarında eşi olan seslerin asgari ölçüde kullanılması (duyumda birbirine benzeyen seslerin belirlenip kolay ayırt edilebilmesi);

- Sesin tam telaffuzu (verilen fonetik öğelerin tam duyulabilmesi);

- Cümle bölümü (dinlenilen cümledeki öğe yani kelime sayısının belirlenmesi);

- Tonlama tipinin belirlenmesi (okunan cümlelerde tonlamalara uygun olarak noktalama işaretlerinin belirlenmesi);

- Tonlamanın yoğun olduğu yerin belirlenmesi (tonlamanın yükseldiği yere dikkat ederek cevabın bulunması);

- Cümle ve kelime telaffuzunun doğru yapılması (telaffuz yapılırken mimikler ile doğru tepkinin verilmesi);

- Telaffuz esnasında gerçekliğin sağlanabilmesi (metin okunurken benzer sesli kelimelerin doğru okunuşunun sağlanması); 
Test system as a means of assessment in Russian language teaching and usage of test system in teaching Russian / H. Parlak (pp. 520-538)

- Konuşan öğrenciye sorulacak (Ne dedin? Tekrar eder misin?) soruları ile söylenen benzer sesli kelimelerin anlaşılıp yazıya dökülmesi;

- Okutulan cümle veya metinlerde önemli ve vurgulu olan kelimelerin belirlenmesi (duygusal açıdan cümlenin önemli olan kelimelerinin belirlenmesi);

- Konuşan şahsın (Kim konuştu?, Kim cevapladı?) gibi sorular sayesinde tespit edilmesi (bu çalışma edebi metinlerin okutulması esnasında diyaloglar ile yapılabilecek bir çalışmadır);

Verilen konuların pratik uygulaması kısmında kullanılacak olan testlerin içeriğinde bulunması gereken çalışmaları şu şekilde sıralayabiliriz:

- Sesli okuma (öğrencinin okurken yaptığı yanlışları görebilmesi için ses kaydı yapması talep edilebilir);

- Sözlü çeviri (ana dillerinde kendilerine verilen kelime ve cümlelerin sözlü çevirisi istenebilir);

- Doğru harfi belirleme (kelime içerisinde boş bırakılan yerlerdeki harfleri dinlerken doğru olarak tespit etme);

- Boşlukları doldurma (okuma esnasında dinlenen cümle içinde boş bırakılan kelimeleri veya kelime içerisinde boş bırakılan harfleri yazma);

- Gereksiz kelimenin tespiti (dinleme esnasında teste verilen şıklar arasındaki çeldiricileri eleyip doğru kelimeyi bulma);

- Noktalama işaretlerinin konulması (okuma veya dinleme esnasında verilen cümlelerin yapısına dikkat ederek noktalama işaretlerinin yazılması);

- Konuşmalarda doğru ve yanlışın bulunması (soruya verilen cevaba göre şıklardaki doğru ve yanlışın tespit edilmesi);

- Ses kaydının yapılması (metinde vurgusuz halde verilen kelimelerin öğrenci tarafından okunması esnasında ses kaydının yapılıp yanlışlarının tespit edilmesi).

Kelime bilgisi ve gramer kontrolü için yapılan testler:

Öğretilen kelime ve gramer becerilerinin öğrenciler tarafından hangi seviyede anlaşıldığını ölçebilmek için verilen testler şu belirteceğimiz özellikleri içermelidirler;

- Öğretilen konuların orantılı olarak verilmesi;

- Testlerin çok şıklı testler olması;

- Verilen yarım cümlelere ekleme yapılması;

- İsmin cinsi, fiilin zamanı, sıfatların sınıflandırılması ve benzeri çalışmaları içermesi;

- Verilen şıklar arasında seçim yapma (şıklarda uygun bir cevap yok ise öğrencinin alternatif şık belirleyebilmesi); 
- Verilen metin içerisindeki gereksiz kelimenin çıartılması;

- Boşluk doldurma (cümledeki boşlukları testte verilen kelimeler ile doldurulması); vb.

Kelime ve gramer bilgisini kontrol etmek için kullanılan testler oldukça basit olan yapıları ile göze çarparlar. Bu testler öğrenciye yol gösterecek olan açıklamaları ve örnekleri içerirler.

Konuşma becerilerinin ölçümü için yapılan testler:

Öğrencilerin konuşma becerilerinin seviyesini ölçerken kullanılan diyalog ve monolog şeklindeki testlerin içereceği çalışmaları şu şekilde sıralayabiliriz:

- Röportaj (karşılıklı fikir alış verişi);

- Tartışma (bir konu hakkında kendi yorumunu katarak konuşma);

- Soru-cevap şeklinde konuşma;

- Sözlü sunum;

- Tiyatro oyunu canlandirma;

- Verilen bir görselin anlatılması;

- İki öğrenci arasında gerçekleşen diyalogda geçen bilgilerin sınıflandırılması;

- Öğretmen ve öğrenci arasında gerçekleşen diyalogda geçen bilgilerin sınıflandırılması;

Konuşma testleri hazırlanırken eğitimciler öğrencilerin şahsi özelliklerini göz önünde bulundurmalıdır ve değerlendirme yaparken ise oldukça objektif olmalıdırlar. Testler, sınıf içi etkinlikleri de destekler nitelikte olmalıdır. Sınıf içinde dil hangi amaçlar için kullanılıyorsa o amaçlara yönelik hazırlanmalıdır (Lee, 2000, akt. Altmışdört, 2010, s. 176). Ölçme-değerlendirme, derslerde olan etkinlikleri doğrudan içine almalıdır. Bu nedenle, ölçme-değerlendirme, ders etkinlikleri ile tamamıyla uyum sağlamak zorundadır. Bunların yanında, testin dış görünüşü, yapısı ve süresi de dikkat edilmesi gereken unsurlardandır (Snow, 1997, akt. Altmışdört, 2010, s. 176).

Konuşma becerilerini ölçmede kullanılan testler bağımsız (herhangi bir konuya bağlı olmayan), bütünleştirici (tüme varım ve çıkarım yaptıran) ve doğaçlama olarak birkaç türe ayrılırlar.

Testler ve test uygulanan öğrencilerin verdikleri cevaplar sayesinde öğrencilerin sinav esnasında karşılaştıkları zorlukları da ortaya koymaktadır. Özellikle ses kayıt cihazı ile yapılan testler esnasında öğrencilerden bazılarının konuşurken heyecan dolayısı ile gereksiz duraksamalar yaptıkları ve doğal konuşma ortamından uzaklaştıkları gözlemlenmiştir. Ses kayıt cihazlarının test sisteminde aktif olarak kullanımı öğrencilerin yaşadıkları toplum önünde konuşma korkularının da zamanla aşılmasına yardımcı olmaktadır. 
Test system as a means of assessment in Russian language teaching and usage of test system in teaching Russian / H. Parlak (pp. 520-538)

Okuma becerilerinin ölçümü için yapılan testler:

Okuma becerisini ölçmek için hazırlanan testler metin içerisinde geçen asıl bilginin anlaşılmasına yöneliktirler. Bu tip testlerde güncel, ilmi, biyografi ve reklam metinlerinin kullanılması tavsiye edilmektedir.

Okuma becerisini ölçen testleri şu şekilde sınıflandırabiliriz:

- Çoktan seçmeli testler (soru sorma ve onaylatma şeklinde olan testler);

- Verilen öğeler ile boşluk doldurma şeklinde olan testler (onaylama ve metin içeriğinden anlaşılan kelime anlamlarının yazılması şeklinde olan testler);

- Doğru ve yanlışın belirlenmesine yönelik testler;

Okuma testlerinde kullanılan alıştırma türlerine kısaca örnek şu örnekleri verebiliriz;

- Reklamı okuyunuz. Bu reklamı okuyan bir şahsın ne yapması gerektiğini yazınız.

- Yarım bırakılan cümleyi okuyup cümleyi tamamlayacak olan kısmı seçeneklerden bulunuz.

- İzlemek istediğiniz filmi seçebilmek için aşağıda verilen film içeriklerini okuyup alıştırmaları yapınız...

Dinleme becerisini ölçmeye yönelik testler:

İ.A.Ganchar'ın fikrine göre pedagojik anlamda kullanılan dinleme testleri hem öğretici hem çalıştırıcı hem de sinava tabi tutucu olmalıdır. Dinleme testlerinin amacı okuma veya ses kaydından dinlenen metin içeriğinin anlaşılma seviyesini ölçmektir. Bu testlerin içerdiği çalışmaları şu şekilde sıralayabiliriz:

- Metnin ana konusunu veya içeriğinde bahsedilen problemi belirleme;

- Metin içeriğindeki asıl veya ikinci derece önem taşıyan bilgileri belirlenme;

- Ayrıntı veren, tasvir yapan, kanıt içeren ve tekrarlayan bilgilerin birbirinden ayrıştırılıp sinuflandirlması;

- Metin bölümleri arasındaki anlam birliğinin sağlanması; (Балыхина, 200о, стр. 91-92)

Dinleme testlerinde olması gereken özellikleri şu şekilde sıralayabiliriz:

- Çoktan seçmeli olması (şıklar arasında doğru olan tek şık olup çeldiricilerin bulunması);

- Farklı görevleri içeren toplu test şeklinde olması (dinlenen metnin içeriğine dayanarak doğru ve yanlışın tespit edilmesi);

- Tüm sınıfın bir testi birlikte cevaplaması;

- Dinlenen metnin sözlü veya yazılı olarak sunulması; 
- Verilen bir tablonun dinlenen metne göre doldurulmasi;

- Dinlenen metin için verilen testin belli bir süre içinde yapılması (örneğin her şık için 30 sn. verilmesi gibi);

- Verilen testin dinleme sonrası veya dinleme esnasında doldurulmasına yönelik sorular içermesi;

Örneğin temel seviyedeki bir dinleme testinin içeriğinde şu tip alıştırmalar bulunabilir:

- Metni dinleyin ve metin içerisinde geçen eş anlamlı kelimeleri belirleyin.

- Diyalogu dinleyin ve boş bırakılan yerleri doldurun.

- Metni dinleyin ve soruları cevaplayın.

Yazım becerilerini ölçmeye yönelik testler:

Yazım becerilerini kontrol etmeye yönelik testler aşağıda belirtilen çalışma türlerine sahiptirler;

- Bilgi ileten mektup yazılımı;

- Verilen konu başlıklarından birisine cevap yazımı (Örneğin: işe girmek için kendi hakkınızda bilgiler yazınız, konuya yorum yazınız, işe başvuru dilekçesi yazınız, okuduğunuz kitaba yorum yazınız, okuduğunuz makaleye yorum yazınız, verilen konu hakkında kompozisyon yazınız).

Yazı becerilerine ölçmeye yönelik testler hazırlanırken öğretmenleri en çok yazıyı değerlendirme ölçütlerini belirleme yönü zorlamaktadır. Yapılan bir yazım testinin kontrolü esnasında dikkate alınması gereken ölçütler şu şekilde sıralanabilir:

- Yazının verilen konuya olan uygunluğu;

- Kullanılan cümle yapısının öğretilen bilgileri karşılayıp karşılamadığı;

- Öne sürülen fikirleri kanıtlayıcı delillerin olması;

- Öğretilen kelime ve gramer yapılarının kullanıp kullanılmadığı;

- Kullanılan kelime gramer yapılarının doğruluğu;

- Yazım ve imla kurallarının doğruluğu;

- Cümle yapılarının doğruluğu;

Uygulanan testleri değerlendirmeye geçmeden önce öncelikle dikkate alınması gereken ölçütleri ve bu ölçütlerin sayısal karşılığını da belirlemek gerekir.

Rus dilinin yabancı dil olarak öğretilmesi esnasında Rusçanın daha yoğun kullanılması ile öğrencilerin ilgi ve isteğinin yükseltilmesi iki unsur sayesinde mümkün olabilir: 
Test system as a means of assessment in Russian language teaching and usage of test system in teaching Russian / H. Parlak (pp. 520-538)

- Gerçeğe yakın iletişim ve ödev ortamları yaratarak öğrencilerin ilgisini çekip sınıf içi ve sınıf dışı çalışmaların yapılması;

- İletişimin farklı alanlarında güncel bilgilerin hızlı iletimini sağlayan teknolojik imkânlardan dil öğretimi alanında faydalanılması. (Артемьева , Макеева, \& Мильруд, 2005, стр. 11)

\section{Yorum ve tartışma}

Yabancı dil eğitiminin teori ve pratiğinde iki tip test sisteminin ön plana çıtı̆̆ı belirlenmiştir: Standartreferans testi (norm - referenced test) ve ölçüt-referans testi (criterion - referenced test).

$\mathrm{Bu}$ testlerden ilki öğrencilerin eğitimsel başarılarını karşılaştırmaya yöneliktir. Bu tür testler öğrencilerin eğitimini aldıkları dildeki bilgi seviyelerini ölçerek onları gruplara ayırmada kullanılmaktadır. İkinci tür ise öğrencilerin eğitimini aldıkları dildeki bilgileri hangi seviyede öğrendiklerini belirlemeye yöneliktir. İkinci tür testler günümüzdeki yabancı dil öğretim sürecinde daha yoğun kullanılmaktadır. (Фоменко, 2008, стр. 73)

Rusçanın yabancı dil olarak öğretilmesi esnasında kullanılacak olan testler hazırlanırken dikkat edilmesi gereken bir husus ise hazırlanan soruların öğretilen konuları tam açılım ile gösterip göstermediğidir. Dil öğretimi için hazırlanan testler hazırlanış şekillerine göre bazı ayrıntılar içerse de genel olarak dil ağırlıklı testler ve diyaloga yönelik testler olarak ikiye ayrılabilir. Dil ağırlıklı testler genelde kelime, gramer ve fonetik bilgilerini ölçmeye yönelik olurken diyalog ağırlıklı testler ise öğrencilerin konuşma becerilerini ölçmeye yöneliktirler.

Yabancı dil eğitiminde ne kadar yöntem ve araç kullanılırsa kullanılsın yabancı dil eğitimi kültürler arası iletişimi sağlayabilecek derecede iyi bilgiye sahip ve aynı zamanda işinin uzmanı olan öğretmenlere her şeyden daha fazla ihtiyaç duymaktadır. Günümüz Türkiye'sinde birçok yükseköğretim kurumunda dil eğitimi alan öğrenciler, öğrendikleri dilin tüm zenginliklerini üniversite eğitimleri boyunca almaları imkânsız bir durumdur ve bu durum ise oldukça normaldir. Mühim olan öğrencilerin dil seviyesini gelecekte çalışmayı planladığı alanda kullanırken zorlanmayacağı ve kendisine lazım olan yazılı ve sözlü bilgileri rahat bir şekilde algılayabileceği bir seviyeye getirebilmektir. Öğrencilerin dil seviyesini istenilen düzeye getirebilmek için ise öğretmen yeterli donanıma sahip olmalıdır. Kısacası kendi alanında yeterli bilgiye sahip olmanın yanında öğrenciler için en uygun eğitim materyallerini seçmeli, öğrencilerin hem ders içi hem de ders dışı çalışmalara aktif bir şekilde katılımlarını sağlamalı ve öğrencilere vermiş olduğu bilgilerin kontrolünü yaparken etkili ve kesin yöntemleri kullanmalıdır.

Rusçanın ve diğer yabancı dillerin eğitiminde kullanılan kontrol sistemlerinin amacı; edinilen bilgiyi kontrol etmenin yanında verilen bilgiyi daha iyi öğretme, eğitim sürecini geliştirme, etkisi az olan yöntemler yerine daha etkili yöntemleri kullanma, daha iyi bir eğitim ortamı hazırlama ve dil pratiğini bir üst seviyeye taşıyabilme amaçlarını da gütmelidir.

\section{Sonuç}

Sonuç olarak test sisteminin Rus dili eğitimine ve genel olarak yabancı dil eğitimine katmış olduklarını şu şekilde sıralayabiliriz:

1. Öğrenci temelli öğretim esnasında öğrencilerin şahsi zihniyetlerinden kaynaklanan zorlukları en aza indirerek öğrenilmesi gereken bilgilerin daha çabuk anlaşılmasını sağlar. 
2. Elde edilen test sonuçlarına göre öğrencilerin bireysel özelliklerinin (içe kapanık, dışa dönük, duygusal, iyi organize olmuş, heyecanlı vb.) belirlenip dil eğitimini bireye yönelik hale getirir.

3. Eğitim süreci üzerindeki hızlı kontrolü mümkün kılar.

4. Eğitim sürecinde esnekliği sağlar.

5. Yapılan sınavlar sonucunda daha net değerlendirme yapabilme imkânı sağlar.

6. Sinav sisteminde yaratıcılı̆̆ı arttırır.

Test sisteminin yabancı dil eğitiminde kullanılması bilgi kontrolünü sağlamanın yanında öğrenilmesi gereken konuların daha çabuk öğrenilmesini de sağlamaktadır. Test sistemi sayesinde yapılan sınavlar öğrencilerin edindiği bilgileri teorik ve pratik açıdan ölçmenin en kolay, hızlı ve ekonomik yoludur. Sınav sonuçlarının yorumlanması ile eksik kalan bilgilere müdahale daha çabuk gerçekleşmektedir.

Yalnız, dil eğitiminde kullanılan testler sonucunda elde edilen değerler ne kadar yüksek olursa olsun bu durum öğrencinin eğitimini aldığı dilde sorunsuzca iletişim kurabildiği anlamına gelmez. Testlerin yabancı dil eğitim sistemine olan en büyük faydası eksik kalan konuların kesin ve hızlı olarak belirlenmesini sağlamasıdır. Yabancı dil eğitiminde kullanılan testler arasında kullanımına yakın zamanlarda başlanan dil pratiğine yönelik testler hazırlanmaları bakımından uzmanları en çok zorlayan testlerdir. Bu testlerin hazırlanmasında söz konusu olan durum dil pratiğinin testler sayesinde nasıl ölçülebileceğidir.

Dil pratiği seviyesini test yardımı ile ölçebilmemiz için yapılması gereken ise; birinci olarak öğretilen konulara yönelik diyalog yapılarından istifade etmek ve ikinci olarak ise test sistemine yardımcı olacak ek kontrol yöntemlerini kullanmaktır. Dil pratiğinin arttırılması için yapılması gereken başka bir çalışma ise öğrencileri klasik sorular yardımı ile kendi başlarına cümle kurmaya yönlendirmek olacaktır. $\mathrm{Bu}$ durumun gerekliliğini öğrencilerimize uygulamış olduğumuz örnek sınavların sonuçları bize göstermektedir.

Sonuç olarak öğrencilere verilen yabancı dil bilgilerinin ölçülebilmesi ve dil eğitiminin gerektiği şekilde yapılabilmesi için kesin ve hızlı sonuç veren kontrol sisteminin oluşturulması ve aynı zamanda dil pratiğinin geliştirilmesi oldukça önemlidir.

\section{Kaynakça}

Altmışdört, G. (2010). Yabancı Dil Öğretiminde Nasıl Bir Ölçme-Değerlendirmeye Gerek Vardır. Kuramsal Ĕ̈itimbilim Dergisi, 175-200.

Karakuş, B. (2013). Üniversite Yabancı Dil Hazırlık Sınıflarında Uygulanan Modüler Sistemdeki Ölçme ve Değerlendirme. Eğitim ve Öğretim Araştırmaları Dergisi, 15-22.

Аванесов, В. (2002). Композиция тестовых заданий. Москва: Центр тестирования.

Артемьева , О., Макеева, М., \& Мильруд, Р. (2005). Методология организаций професиальной подготовки спецалиста па основе межкультурной коммуникации. Тамбов: Издательство ТГТУ.

Балыхина, Т. (2000). Профессионально-ориентированное тестирование и проблемы глобализации профессий. Мир русского слова, 57-61.

Кадневский , В. (2004). История тестов. Москва: Народное образование. 
Test system as a means of assessment in Russian language teaching and usage of test system in teaching Russian / H. Parlak (pp. 520-538)

Олейник, Н. (1991). Тест как инструмент измерения уровня знаний и трудности заданий в современной технологии обучения. Донецк: Донецкий государственный университет.

Помякшева, Н. (2009). Тест, как форма контроля знании студентов 1 - 2 курсов применяемая на дисциплине «математика и информатика». Педагогические чтения на комиссии гуманитарных социально-экономических дисциплин, 2009 - 2010 учебный год, (стр. 5659). Самара.

Фоменко, Т. (2008). Французский язык. Тесты как форма контроля. Москва: Просвещение. 